\title{
Appraisal of Asiatic Hybrid Lilium Cultivars under Polyhouse Growing Condition in Semi-Arid Haryana, India
}

\author{
Sonu Kumar*, Arvind Malik, D. S. Dahiya and Manpreet Kaur \\ Department of Floriculture and Landscape, CCS HAU, Hisar-125-004, Haryana, India \\ *Corresponding author
}

\section{A B S T R A C T}

\section{Keywords}

Lilium, cut flower,

cultivars, Nashville,

Eyeliner and Hyde Park

Article Info

Accepted:

22 May 2018

Available Online:

10 June 2018
Appraisal of Lilium cultivars namely, Nashville (Yellow), Eyeliner (White) and Hyde Park (Orange) was carried out at Centre for Quality Planting Material, CCS Haryana Agricultural University, Hisar (Haryana) during winter season of 201718 to identify the suitable cultivar for successful cultivation and flower production under polyhouse growing conditions. The results reveal that among different cultivars, the cultivar Nashville had the towering plants with maximum leaf number, largest flower with maximum flower diameter $(20.81 \mathrm{~cm})$ and more number of flowers per plant (4.47).

\section{Introduction}

Floriculture or flower farming is a discipline of horticulture concerned with the cultivation of ornamental plants for trade and floristry. India is bestowed with several agro-climatic zones conducive for the production of sensitive and delicate floriculture produce. Lilies (Lilium species) are very important ornamental bulbous plants belonging to the family Liliaceae. It is one of the leading cut flowers and ranks fourth among the top cut flowers in the world. It bears beautiful, attractive and bright flowers with shelf life. The genus Lilium with 100 species is native to Asia, Europe and Northern America in Northern Hemisphere (McRae, 1998). Asiatic hybrid lily can be multiplied through seeds, bulb scales, bulb division, stem bulblets and stem bulbils. Stem bulblets and bulb divisions are suitable for it propagation. The number and size of bulb and bulblets depend upon the growth of lily plants. The optimum size of bulb, growing conditions and depth of planting is required for proper development and growth of plants. In LA the main colour is the yellow, followed by orange and pink, both decreased 4.9 and $19.4 \%$. White is the most increased colour, with an increase of $53.1 \%$, while the highest reduction is possible to observe in the gray colour. Regarding Asiatic hybrids, with $44.1 \%$, the orange colour is the most important, followed by yellow. The price of cut flower stems varies among different groups of lilies. The highest prices are for Oriental, with red colour the highest and with pink the lowest price. The red and brown 
colours have the highest price in Longiflorum asiatic and Asiatic hybrids, respectively. Lilium flower crops in India are on rise with a production of 8000 number per tons of cut flowers (Saxena, 2014).

Among the different types of lily, the Asiatic hybrid lily is very popular and high income generating per unit area. It is widely used in the floral industry as cut flower and potted plant, which are prized higher due to their size, beauty and longevity (Thakur et al., 2005). The popularity of Lilium is gaining momentum in the country due to its large and attractive flowers with rehydration capacity after a long transportation. The cultivars of genus Lilium with outstanding range of colour, fragrance and adaptability to several environmental conditions are highly appreciated by the horticulturists (Bahr and Compton, 2004). The popularity of these hybrids, especially Asiatic and oriental types is increasing both as cut flower and pot plant (Lian et al., 2003).

Appraisal of cultivars is of immense importance as different cultivars differ in their colour, stems length and number of flowers, which affect the economics of cultivation to a large extent. In Haryana, Lilium crop, which increased from 2.0 hectors with a production of 2,40,000 sticks in 2012-13. Presently, area under cultivation is 50.84 hectare with a production of 1,90,37,200 sticks (HDH, 2016). Information on minor cut-flower crops such as Allium, Brodiaea, and Anemone has been published (De Hertogh, 1989) and data are also available concerning yield, planting time, and effects of longevity on yield and flower quality (Armitage, 1987). The successful cultivation of Lilium depends on selection of suitable variety. The study of cultivars is very important for standardizing the production technology and its transfer to farmers' field. Study of the performance of commercially important cultivars with varying growth habit, shape, size and colour of flowers will enable the farmers to make choice according to the market demand

\section{Materials and Methods}

The experiment was conducted at Centre for Quality Planting Material, CCS Haryana Agricultural University, Hisar (Haryana) during winter season of 2017-18 to study the appraisal of asiatic hybrid lilium for cut flower production. The experimental site was located in semi-arid zone of western Haryana at an altitude of 215 meters above mean sea level, latitude $29.09^{\circ} \mathrm{N}$ and longitude $75.43^{\circ} \mathrm{E}$. The maximum temperature remained around $45^{\circ} \mathrm{C}$ during summer months of May to June and average annual rainfall of the region about 450 $\mathrm{mm}$ received during July to September. The three cultivars namely, Nashville, Eyeliner and Hyde Park were laid out in randomized block design (RBD) and replicated thrice. The bulbs were planted in the last week November at row to row and bulb to bulb spacing of $30 \times 20 \mathrm{~cm}$ under polyhouse conditions. The cultural operations were followed throughout the experiment as per the package of practices to grow a healthy crop. The data recorded on various growth and flowering parameters were analysed statistically with the help of window based computer package OPSTAT. The calculated value of ' $r$ ' was compared with ' $t$ ' table value with $n-2$ degrees of freedom at $5 \%$ level of significance, where, $\mathrm{n}$ referred to number of pairs of observations.

\section{Results and Discussion}

The data given in Table 1 revealed that the maximum plant height $(123.73 \mathrm{~cm})$ was recorded in Nashville and followed by the cultivars Eyeliner $(112.87 \mathrm{~cm})$. However, lowest plant height was associated with cultivar Hyde Park $(104.60 \mathrm{~cm})$. The significant variation with respect to plant height among the Lilium cultivars were 
noticed by Barik and Mohanty (2015), Sindhu and Singh (2012) under northern plains. Cultivar Nashville revealed that maximum $(99.60 \mathrm{~cm})$ stem length which was followed by Eyeliner and Hyde Park $(87.40,83.27 \mathrm{~cm})$ respectively which was significantly differ from each other.

The minimum days to sprouting observed in cultivars Nashville (6.6days) followed by cultivar Eyeliner (7.4days) and maximum days taken to sprouting in Hyde Park (8.2days). Percent sprouting of bulbs observed (100\%) in all cultivars which was none significantly differed to each other. Various cultivars none significantly difference for sprouting has been also reported by Sindhu et al., (2012), Barik and Mohanty (2015).

Cultivar Eyeliner recorded maximum number of leaves (65.07) per plant followed by cultivar Nashville which recorded (62.33) leaves per plant respectively. On other hand the minimum (54.00) leavers per plant was recorded in Hyde Park. Leaves length also reported maximum in cultivars Nashville $(14.57 \mathrm{~cm})$ followed by Eyeliner $(9.29 \mathrm{~cm})$ which was at par with Hyde Park $(8.45 \mathrm{~cm})$. Width of leaves was maximum $(2.36 \mathrm{~cm})$ in Nashville which was significantly differed from other it was followed by Eyeliner $(2.10 \mathrm{~cm})$ respectively. The minimum leaves width $(1.45 \mathrm{~cm})$ was recorded in Hyde Park. The maximum basal stem diameter reported in cultivar Nashville $(11.25 \mathrm{~mm})$ followed by Eyeliner $(8.16 \mathrm{~mm})$ and minimum basal stem diameter was recorded in cultivar Hyde Park $(6.49 \mathrm{~mm})$ the data presented in (Table 2). Similarly variation in vegetative traits of lilium has been reported by Singh et al., (2015), Barik and Mohanty (2015) and Deka et al., (2010). Differences in vegetative characters of different cultivars of lilium may be due to varied growth rates and their genetic potential resulted in variation in phenotypic expression. Kim et al., (2013) and Pandey et al., (2008) reported similar result of vegetative growth in Asiatic hybrid lily.

Lilium cultivars various significantly differ for quality and flowering traits presented in (Fig1). Days to emergence of bud and days to colour change of first bud were advanced in cultivars Hyde Park (33.40 and 73.07days) which was at par with Eyeliner (34.93 and 77.20days), whereas, delayed emergence of bud and colour change of first bud was observed in cultivar Nashville (37.93 and 85.47). Minimum days to open first flower was observed in cultivars Hyde Park (93.73days), which was remained at par with Eyeliner (103.53days). However, maximum days to open of first flower were reported in Nashville (106.40days). Similar variation among the cultivar traits was also reported by Kumar et al., (2011), Sindhu and Singh (2012) in Lilium.

Table.1 Performance of lilium cultivars for vegetative characters

\begin{tabular}{|c|c|c|c|c|}
\hline Cultivar & Days to sprouting & Percent sprouting & Plant height (cm) & $\begin{array}{c}\text { Stem length } \\
(\mathbf{c m})\end{array}$ \\
\hline Nashville & 6.6 & 100 & 123.73 & 99.60 \\
\hline Eyeliner & 7.4 & 100 & 112.87 & 87.40 \\
\hline $\begin{array}{c}\text { Hyde } \\
\text { Park }\end{array}$ & 8.2 & 100 & 104.60 & 83.27 \\
\hline $\mathrm{CD}_{0.05}$ & 0.5 & N/A & 6.25 & 5.52 \\
\hline
\end{tabular}


Table.2 Appraisal of lilium cultivars for their performance of vegetative characters

\begin{tabular}{|c|c|c|c|c|}
\hline Cultivar & $\begin{array}{c}\text { Stem diameter } \\
(\mathbf{m m})\end{array}$ & $\begin{array}{c}\text { No. of leaves per } \\
\text { plant }\end{array}$ & Leaves length $(\mathbf{c m})$ & $\begin{array}{c}\text { Leaves width } \\
(\mathbf{c m})\end{array}$ \\
\hline Nashville & 11.25 & 62.33 & 14.57 & 2.36 \\
\hline Eyeliner & 8.16 & 65.07 & 9.29 & 2.10 \\
\hline Hyde Park & 6.49 & 54.00 & 8.45 & 1.45 \\
\hline CD $_{0.05}$ & 0.16 & 4.14 & 1.22 & 0.10 \\
\hline
\end{tabular}

Table.3 Performance of lilium cultivars for flowering characters

\begin{tabular}{|c|c|c|c|c|}
\hline Cultivar & $\begin{array}{c}\text { No. of flowers } \\
\text { per plant }\end{array}$ & $\begin{array}{c}\text { Flower bud } \\
\text { length }(\mathbf{c m})\end{array}$ & $\begin{array}{c}\text { Flower bud } \\
\text { diameter }(\mathbf{m m})\end{array}$ & $\begin{array}{c}\text { Flower diameter } \\
(\mathbf{c m})\end{array}$ \\
\hline Nashville & 4.47 & 10.37 & 34.20 & 20.81 \\
\hline Eyeliner & 3.27 & 9.88 & 31.97 & 19.48 \\
\hline Hyde Park & 2.87 & 9.57 & 26.57 & 18.79 \\
\hline CD $_{0.05}$ & 0.54 & 0.58 & 2.34 & 1.10 \\
\hline
\end{tabular}

Fig.1 Appraisal of lilium cultivars for their performance of flowering characters

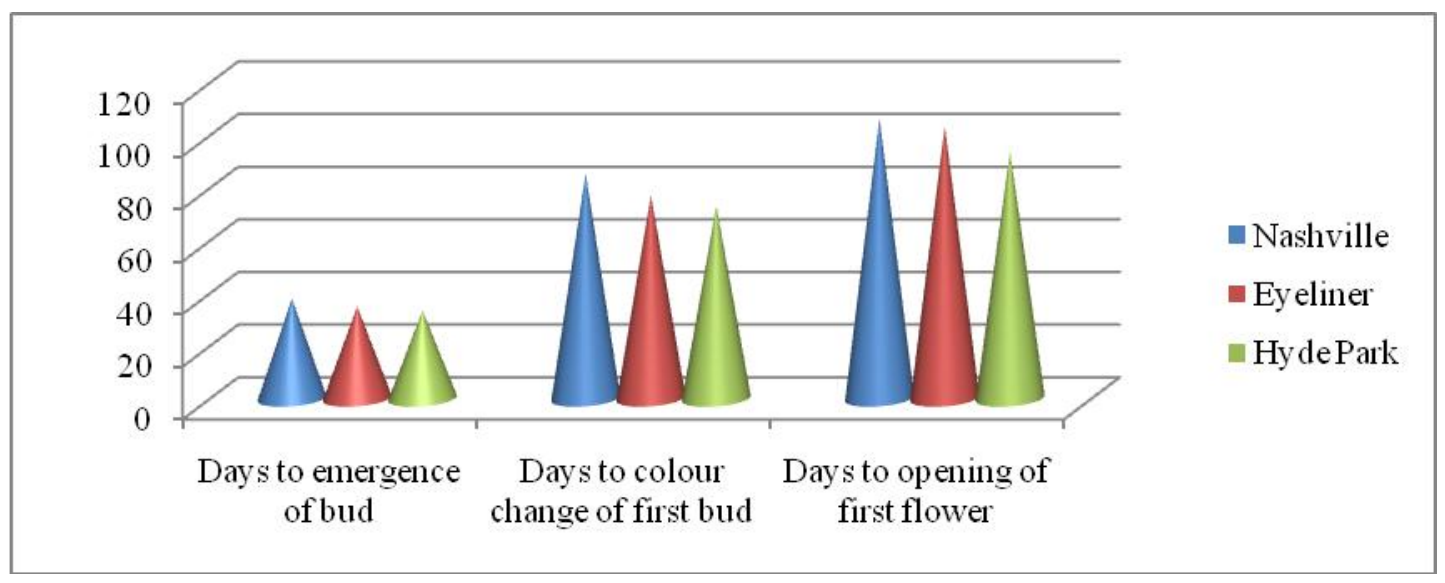

Data pertaining to cultivars Nashville showed maximum flower diameter, flower bud diameter $(20.81 \mathrm{~cm}, 34.20 \mathrm{~mm})$ followed by Eyeliner $(19.48 \mathrm{~cm}, 31.97 \mathrm{~mm})$ and lowest flower diameter, flower bud diameter was observed in cultivar Hyde Park $(18.79 \mathrm{~cm}$, $26.57 \mathrm{~mm}$ ). Flower bud length of the Lilium flower crop was observed maximum in cultivar Nashville $(10.37 \mathrm{~cm})$ which was at par Eyeliner $(9.88 \mathrm{~cm})$, while, minimum flower bud length observed in cultivar Hyde Park $(9.57 \mathrm{~cm})$. Maximum number of flower per plant is an important parameter of Lilium crops are always preferred which fetch maximum price in market. In present study significant variation in number of flower was observed due to different cultivars tried. The maximum number of flower per plant reported that in cultivars Nashville (4.47) followed by cultivar Eyeliner (3.27) and lowest number of flower per plant observed by cultivar Hyde Park (2.87) the data presented in table 3. Similar trend of flower character has been observed by Barik and 
Mohanty (2015), Negi et al., (2014), Deka et al., (2010), Srinivas (2002) in lilium cultivar. Wide variation in flower traits due to cultivars has also been reported by Dhiman (2003) and Singh et al., (2016). Pandey et al., (2012) reported the same variation in gladiolus.

Based on the overall results, appraisal of different cultivars of lilum, cultivar Nashville showed better performance for vegetative, flowering and quality characters under polyhouse growing condition of western Haryana, Hisar district and recommended for its commercial cultivation.

\section{References}

Armitage, A.M. (1987). The influence of spacing on field-grown perennial crop. Hort. Sci. 22: 904-907.

Bahr, L.R. and Compton, M.E. (2004). Competence for in vitro bulb regeneration among eight Lilium genotypes. Hort. Sci. 39(1): 127-129.

Barik, D. and Mohanty, C.R. (2015). Evaluation of Asiatic hybrid lily varieties under Bhubaneswar condition. Asian J. Hort., 10(2): 194-200.

De Hertogh, A.A. (1989). Holland bulb force's guide. $4^{\text {th }}$ ed. Intl. flo. Bulb Cen. Hillegrom, The Netherland.

Deka, Rajiv Kumar, Bidyut, C. and Patel, V. V. (2010). Evaluation of Asiatic Lilium under sub-tropical mid hills of Meghalaya. J. Ornam. Hort., 13(4): 257-260.

Dhiman, M.R. (2003). Evaluation of hybrid lily under Kullu conditions. J. Ornam. Hort., 6(2): 154-155.

Haryana Horticulture Statistical data (2016). Horticulture Department, Haryana (HDH).

Kim, M.J., Hong, S.J. and Kim, H.K. (2013). Effect of bulblets size Oriented from tissue culture on growth and bulb enlargement of Lilium Oriental Hybrids grown in highlands. Kor. J. Hort. Sci. Tech. 31(2): 165-172.

Kumar, R., Patel, V., Verma, D., Bidyut, C., Singh, S. and Sindhu, S. (2011). Evaluation of Asiatic lilium under subtropical mid hills of Meghalaya. $A d v$. Res. J. of C. Improv. 2(2): 257259.

Lian, M.L., Chakrabarty, D. and Paek, K.Y. (2003). Growth of Oriental hybrid 'Casablanca' bulblet using bioreactor culture. Hort. Sci. 97: 41-48.

Mc Rac, E.A. (1998). Lilies- a guide for grower and collectors.Timber Press, Portland, Oregon, USA.

Negi, R., Kumar, S. and Dhiman, S.R. (2014). Evaluation of lilium (lilium spp.) Cultivars for low hills of Himachal Pradesh. Ind. J. Sci. Res. and Tech. 2(4): 8-10.

Pandey, R.K., Bhat, D.J., Dogra, S., Singh, A., Laishram, N. and Jamwal, S. (2012). Evaluation of gladiolus cultivars under subtropical conditions of Jammu. Inter. J. Agric. Sci., 8(2): 518-522.

Pandey, R.K., Dogra, Sheetal, Sharma, J.P. and Jamwal, Shivani (2008). Evaluation of Asiatic hybrid lily cultivars under subtropical conditions of Jammu region. J. Plant Sci. \& Res., 24(2): 213-214.

Saxena, M. (2014). Indian horticulture databse. NHB: 12.

Sindhu, S. S., Singh, J.P. and Singh R.K. (2012). Evaluation of lilium cultivars under northern plains. Inter. J. of Agric. Sci. 8(2): 460-461.

Sindhu, S.S. and Singh, J.P. (2012). Evaluation of lilium cultivars under Northern plains. Inter. J. Agric. Sci., 8(2): 460-461.

Singh, M. K., Kumar, S., Ram, Raja and Prasad, R. (2016). Effect of size of bulb, growing conditions and depth of planting on flower and bulb production of Asiatic hybrid lily (Lilium spp) cv. 
Brunello. Ind. J. of agri. Sci. 86(3): 3913.

Srinivas, M. (2002). Response of Asiatic lilies to open cultivation. Abstract, Natioal Symposium on Indian Floriculture in the New Millennium. Feb.25-27, 50-51.
Regulation of growth of Lilium plantlets in liquid medium by application of paclobutrazol or ancymidol for its amenability in a bioreactor system: growth parameters. Pl. Cell Rep. 25: 382-391.

Thakur, R., Sood, A., Nagar, P.K., Pandey, S.,

Sobti, R.C. and Ahuja, P.S. (2005).

\section{How to cite this article:}

Sonu Kumar, Arvind Malik, D. S. Dahiya and Manpreet Kaur. 2018. Appraisal of Asiatic Hybrid Lilium Cultivars under Polyhouse Growing Condition in Semi-Arid Haryana, India. Int.J.Curr.Microbiol.App.Sci. 7(06): 3389-3394. doi: https://doi.org/10.20546/ijcmas.2018.706.398 